\title{
Immunoglobulin a in Chronic Periodontitis Patients
}

\author{
Ibrahim M. S. Shnawa \\ College of Biotechnology, University of Kasim, Kasim, Babylon Governerate/IRAQ
}

\section{Email address:}

ishnawa@yahoo.com

\section{To cite this article:}

Ibrahim M. S. Shnawa. Immunoglobulin a in Chronic Periodontitis Patients. American Journal of Biomedical and Life Sciences. Special Issue: Advances in Oral Immunity. Vol. 3, No. 4-1, 2015, pp. 1-3. doi: 10.11648/j.ajbls.s.2015030401.11

\begin{abstract}
Fourty-nine chronic periodontitis patients were diagnosed by dentist .Of which 27 were with generalized chronic periodontitis and 22 were with localized chronic periodontitis. The disease was prevalent among the age group range from 20 to 44 years old. Ten apparently healthy normal subjects were elected as control .Sera, saliva, salivary proteins were made for detection of IgA levels using radial immunodiffusion in gel containing low and high levels of anti-IgA ready made makes. Periodontitis patients sera have shown that, IgA concentration means reachs two to three folds higherthan that of controls. The IgA herd plot among the patients was of skewd distribution type. Young patients serum IgA were showing higher than that of senescence periodontitis patients and higher than that of normal control subjects .Male patients serum IgA were of higher concentration means than that of female patients. Apparently senescence decreases serum IgA concentration means as compared to young patients and controls.
\end{abstract}

Keywords: Chronic, Periodotitis, Serum, Saliva, Proteins, Plot, Herd

\section{Introduction}

The systemic as well as mucosal immune response time curve of vertebrate including man twards bacterial peptide epitope is initiated and mounted as an IgM response ,then it can be class switched to $\operatorname{IgA}$ or $\operatorname{IgG}$ through gene rearrangement, gene exclusion, gene rearrangement and/or cytokine action[1,2].Hence , IgG or IgA may be concomitant with chronicity state of an infectious disease[3,4].Rise upof either $\operatorname{IgA}$ or IgG or both into two to four folds than that of base line concentration is considered as a holdfast criterion for chronicity[5,6].Though ,oral mucosal tolerance, immune complex deposition in periodontal or salivary gland tissues may lessen or nullifythe concentrations of oralsoft tissue $\operatorname{IgA}[7,8]$.The objective of the current communication was to report on serum and salivary $\operatorname{IgA}$ among chronic periodontitis patients.

\section{Main Body}

Fourty-nine chronic periodontitis patients from both males and females were clinical diagnosed by the specialized dentists[9].Ten apparently normal mouth hygiene subjects were elected as control. Blood samples without anticoagulants in a rate of $5 \mathrm{ml}$ in plane tubes were collected from both patients and controls[10].Likewise ,from both periodontitis patients and controls saliva were collected as recommended by salimeterics [11].Salivary proteins was separated using $6 \%$ polyethylene glycol 6000 as protein precipitant[12]. Radial immunodiffusion in gel containing low and high level anti-IgA [13].Biometeric analysis were done as in Steels et al[14]

\section{Results and Discussion}

The periodontitis patients sera have shown Table 2 immunoglobulin A (IgA) concentration means higher than those of control subjects. They reachs two to three folds than controls. IgA herd plot was found to be of skewd normal distribution curve. Thus, periodontitis induced an increase in serum $\operatorname{IgA}$, and serum IgA among patients can probe herd immunity for the test population Figure 1. Young patients were showing higher serum IgA concentration means than that for senescent patients and that for normal subject controls. Senescent decreases the concentration means as compared to young Figure 2.

Table 1. The study groups

\begin{tabular}{ll}
\hline Disease Entity & Numbers \\
\hline Local chronic Periodontitis & 22 \\
Generalized chronic periodontitis & 27 \\
Control & 10 \\
Total & 59 \\
\hline
\end{tabular}


Table 2. Immunoglobulin A in Periodontitis patients and controls

\begin{tabular}{lllll}
\hline \multirow{2}{*}{$\begin{array}{l}\text { Age } \\
\text { Range/years }\end{array}$} & Control & Total & $\begin{array}{l}\text { Generalized } \\
\text { form }\end{array}$ & $\begin{array}{l}\text { Localized } \\
\text { form }\end{array}$ \\
\cline { 2 - 5 } & 211.0 & 539.55 & 551.1 & 528.0 \\
$35-29$ & 209.4 & 519.113 & 553.6 & 484.626 \\
$35-34$ & 215.4 & 497.76 & 463.2 & 500.52 \\
$40-44$ & 111.8 & 479.161 & 476.7 & 481.772 \\
\hline
\end{tabular}

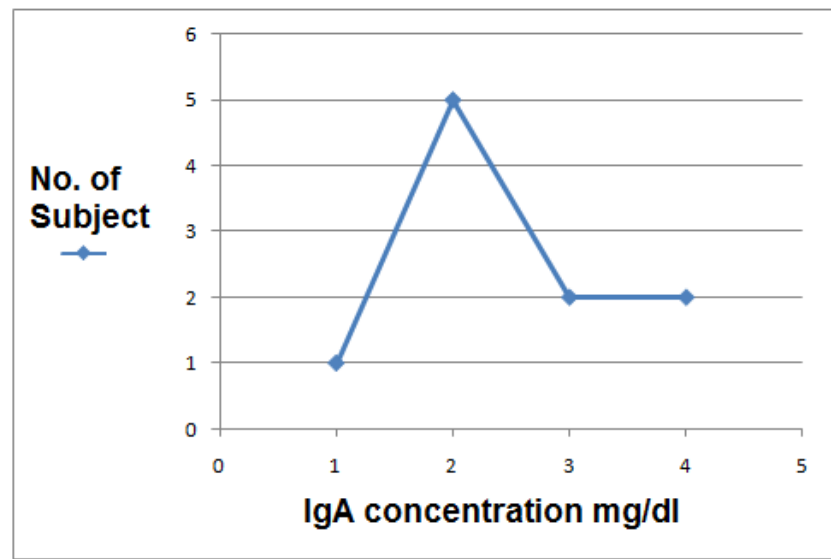

Figure 1 A. IgA concentration among control subjects

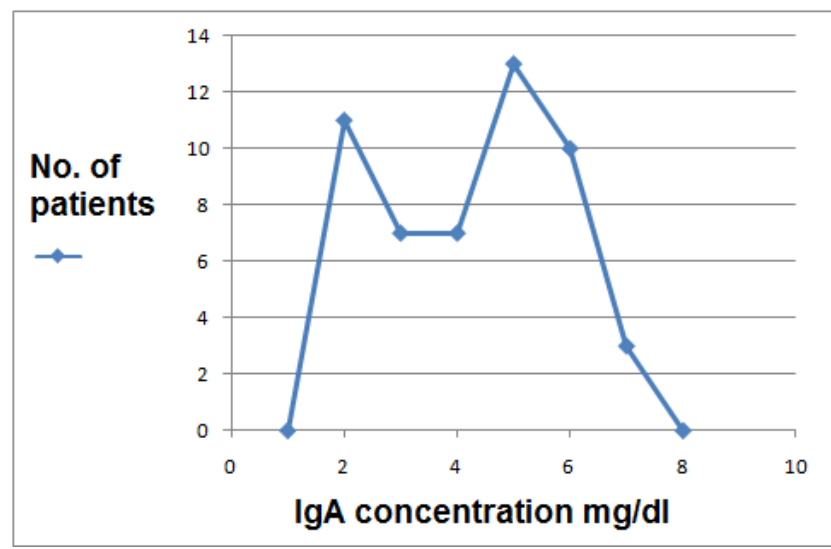

Figure 1 B. IgA concentration among periodontitis patients

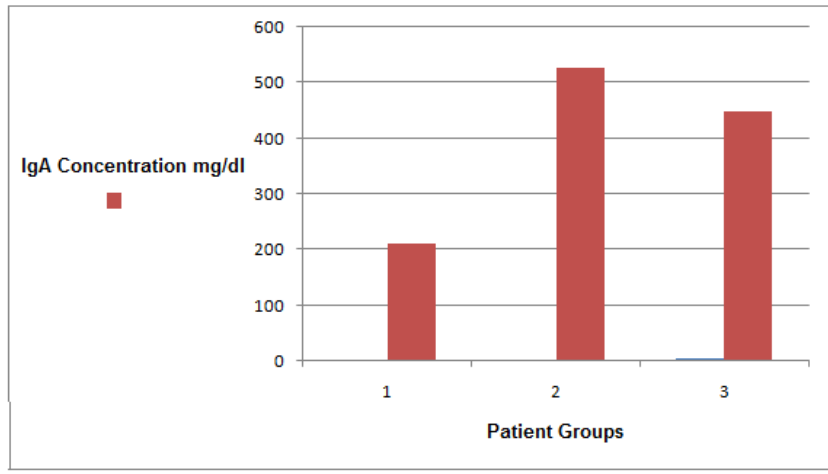

Figure 2. The effect of aging and periodontitis on IgA concentration

Male patients were of higher serum IgA concentration means than that for female patients .Female patients gender seems to be of rather decreasing potential to serum IgA.

Oral soft tissue harbors the IgA-bacterial epitopecomplement complexes leading to vanishing or nullifying the secretory $\operatorname{IgA}$ in saliva and salivary proteins found in this study.

The continual trigger for the immune cells of the oral mucosal compartment by the antigenic epitope(s) of the periodontal pathogens ,such trigger may induced systemic immune responses with initial immunoglobulin $M$ type then after class switched to IgA type[1,17,18].In comparison,IgA seronegative saliva and salivary proteins may be due to either case of stomial mucosal tolerance[19] or due to an immune complex deposition in the periodontal softtissue and/paucity of salivary IgA secretion[19,20,21]

\section{Conclusion}

i- Local periodontal infections stimulates an increasein the levels of systemic IgA.

ii- Systemic IgA accounts both for chronicity and class switching.

iii- Senescent inhibits systemic IgA levels

iv- Gender may interplay an increment or decrement shift in serum IgA in periodontitis patients.

\section{Acknowledgements}

The author wish to thank specialist dentist Zainab ALFatlawy whom diagnose the study cases and Baha $\mathrm{H}$ ALAmiedi ,Ph.D for the help extended by him, both from the college of dentistry, university of Babylon, Babylon governerate.

\section{References}

[1] Doan T, Melvold R, Viselli S, Waltenbaugh C,2008, Immunology, Linppicotts Illustrated Review, Wolter KluwerHealth ,Philadelphia.

[2] Paul W 2003, Fundamental Immunology $5^{\text {th }}$ ed. Lippincott Williams and Wilkins,Philadelphia.

[3] Steward M W 1984, Antibodies; Their Structure And Functions, Chapman and Hall Ltd, London

[4] Abbas AK, Litchman AH, Pober J S, 2000, Cellular And Molecular Immunology, $4^{\text {th }}$ ed. W B Saunders, U.S.A.

[5] Bucci L 2009, Inflammoaging,In Fluop T, Franceschi C, Hirokawa K, Pawelec G (eds) .Handbook on immunosenescence Springer, Netherland.

[6] Goto M 2008, Inflammoaging:A deriving force for human ageing based on evolutionary antagonistic pleotopytheory, Biosci .Trends ,2(6):218-230.

[7] Strober W ,Fuss I J ,2001, Mucosal immune System , In, Parslow TG, Stites DP , Terr AI, ImbodenJB (eds),Medical Immunology $10^{\text {th }}$ ed,Lange Medical Books,New York.

[8] Nikolopoulou-Papconstantinou AA , Johannessen AC, Kristoffsen T, 1987, Deposits of immunoglobulins, complements and immune complexes in inflamed human gingiva, Acta.Odontol. Scand., 45(3):187-199. 
[9] Mills MP, 2013, Immunological and Inflammatory aspects of periodontal disease ,Dental Care continuing education ,course no.1.

[10] Armitage GC 1999, Development of a classification of periodontal diseases, Anns .Periodontol., 4:1-6.

[11] Stevens CD 2010, Clinical Immunology And Serology :A Laboratory perspective, $3^{\text {rd }}$ ed.F.A. Davis Company, Philadelphia.

[12] Salimeterics 2013,Saliva collection and handling, $3^{\text {rd }}$ ed., Saliva B Co.A Salimeterics LLC Co.

[13] Shnawa IMS , AlSadi MAK 2001, Gut mucosal immunoglobulin, separation, partial characterization and utility as infection probe, Irq.J.Microbiol.13(3):

[14] Jonston A, Thorpe R 1982, Immunochemistry In Practice, Blackwell Scientific Publications, London.

[15] Mancini G , Corbonara A O , Heremans JF 1965, Immunochemical quantitation of antigens by single radial diffusion, Immunochem., 2:237
[16] Steel RCD , Torrie JH ,Dickey DA 1997, Priciples And Procedures of Statistics: A biomedical Approach, $3^{\text {rd }}$ ed., McGraw-Hill, New York.

[17] Dumitrescu AL, Kawamura M 2010, Etiology of periodontal disease ,In, Dumitrescu AL ,Etiology and Pathogenesis of Periodotal Diseases ,Springer ,Berlin, Heidlberg.

[18] DumitrescuAL, Tanaka M 2010, Particular Aspects of Periodontal Disease Pathogenicity, In , Dumittrescu $\mathrm{AL}$,Etiology and Pathogenesis Of Periodontal Disease , Spriger ,Berlin ,Heidelberg

[19] Walsh LJ 2008, Clincal aspects of salivary biology for detal clinician .J. Min .Inter . Dntist. ,1(1):7-24.

[20] Boackl RJ 1991, Interaction of salivary secretion with human complement system .A model for study host defence system on inflamed surfaces., Crit.Rev.Oral.Biol.Med., 2(2):355-367.

[21] Olayanju QA, Rahmon SK, Joseph IO, Arinola, 2012, Salivary immunoglobulin classes in Nigerian patients with periodontitis, J.Contm.Dent.Pract., 13(2):163-166. 